\title{
Visi Baru Konselor Sekolah dalam Rangka Meningkatkan Kualitas Layanan Pendidikan di Sekolah dan Madrasah
}

\author{
Ardimen \\ Jurusan Bimbingan dan Konseling, Fakultas Tarbiyah dan Ilmu Keguruan \\ IAIN Batusangkar \\ Email: ardimen@iainbatusangkar.ac.id
}

\begin{abstract}
:
This study aims to describe the new vision of school counselors in order to improve the quality of education services. This study uses library research methods by reviewing reference books, scientific journals, documents, magazines, legislation and the results of similar studies accessed through an open journal system via internet search. The data collected was analyzed by using conten analysis techniques to obtain theories or concepts in answering the problem of this research. The results of the study show that the implementation of a new vision of school counselors can improve the quality of education services in schools and madrasah. To that end, the performance of the school counselor is no longer positioned in the relief effort to overcome the problem of students, but the counselor carries out counseling to help students who are undergoing the process of self-development in order to achieve optimal development, independence and happiness in living life. Among the new visions of the school counselor are; (1) academic focus/ student achievement, (2) building based on student strengths, (3) counselors as program leaders, planners and developers, (4) focusing on academic counseling, learning and achievement, and supporting student success, (5) counseling is an integral part of the education system, (6) counseling services focus on mission and role identification, (7) using data to influence change, etc.
\end{abstract}

Keyword: New Vision, School Counselor, Education Services

Received August 15, 2018; Revised September 21, 2018; Accepted October 01, 2018

How to Cite: Ardimen. (2018). Visi Baru Konselor Sekolah dalam Rangka Meningkatkan Kualitas Layanan Pendidikan di Sekolah dan Madrasah. JKI (Jurnal Konseling Indonesia), 4(1), 22-29.

\section{PENDAHULUAN}

Peningkatan kualitas layanan pendidikan harus terus diupayakan secara terpadu dan berkelanjutan di antaranya melalui reformasi sekolah dan madrasah dengan visi baru konselor sekolah yang bermartabat. Reformasi sekolah dan madrasah hendaknya menghadirkan pendidikan yang berkualitas dalam rangka memfasilitasi perkembangan peserta didik secara optimal. Sejalan dengan itu, (Mustadi, 2018) menyatakan bahwa semangat Reformasi Sekolah dalam kurikulum 2013 diharapkan mampu menjawab tantangan yang ada yaitu bagaimana mewujudkan pendidikan yang berkualitas.

Pendidikan yang berkualitas tentu saja diampu oleh tenaga pendidik yang berkualitas juga. Konselor atau guru BK termasuk salah satu jenis tenaga pendidik di samping guru, dosen, instruktur, fasilitator dan 
sebutan lainnya. Konselor atau guru BK merupakan tenaga pendidik profesional yang memiliki kualifikasi akademik dan kompetensi dalam bidang BK di sekolah dan madrasah harus memiliki visi baru dalam merencanakan dan menerapkan program konseling sekolah yang komprehensif dan bersifat pengembangan dan ini sejalan dengan konsep Gysbers (Gladding, 2012). Dalam hal, ini, kinerja konselor sekolah tidak lagi diposisikan dalam upaya bantuan untuk mengatasi masalah siswa di sekolah dan madrasah, namun 'konselor melaksanakan konseling untuk membantu individu-individu normal yang sedang menjalani proses perkembangan sesuai dengan tahap-tahap perkembangan agar mencapai perkembangan optimal, kemandirian dan kebahagiaan dalam menjalani berbagai kehidupan' (Wibowo, 2017). Di samping itu, kinerja konselor sekolah adalah untuk melakukan upaya sistematis, logis, terprogram dan berkelanjutan dalam rangka memfasilitasi perkembangan peserta didik secara optimal.

Pelayanan konseling di sekolah dan madrasah adalah untuk seluruh siswa (counseling for all) dengan keragaman dan keunikannya. Untuk terwujudnya harapan tersebut, maka pengetahuan, keterampilan dan kepribadian serta cara pandang konselor sekolah semestinya selalu diupdate setiap saat sehingga konselor sekolah mampu menjawab tantangan perubahan. Namun dalam kenyataannya sampai saat ini konselor sekolah belum mampu memenuhi ekspektasi dan harapan tersebut. Hal itu diperkuat oleh studi (Gumilang, 2016b) yang menyatakan bahwa unjuk kerja konselor saat ini belum menunjukkan hasil yang maksimal, sehingga masih banyak kesalahpahaman pada masyarakat mengenai pekerjaan seorang konselor sekolah. Studi tersebut diperkuat oleh studi Rasiyo (Gumilang, 2016a) bahwa di banyak sekolah gambaran kondisi konselor adalah guru yang paling enak pekerjaannya, sering tugas kunjungan rumah, tugasnya ringan, kurang kerjasama dengan guru lain dan guru, ruang BK kurang data tentang perkembangan siswa, kurang eksistensinya karena datang terlambat dan pulang cepat. Ditambahkan Juga oleh Triyono (2012) (Gumilang, 2016b) bahwa kesalahpahaman yang sering terjadi karena konselor senang bekerja sendiri tanpa kolaborasi dengan guru, suka menunggu perintah, kurang disukai siswa, kurang inovatif, menangani pelanggaran siswa saja, dan bergantung pada sumber daya sistem. Untuk mengatasi masalah tersebut, maka beberapa pertanyaan yang ingin dijawab dalam penelitian ini di antaranya adalah [1] bagaimana identitas guru BK atau Konselor di lembaga pendidikan?, [2] bagaimana posisi/ keberadaan BK/ konseling pada satuan pendidikan?, [3] bagaimana mengatasi kesalahpahaman terhadap BK?, dan [4] apa saja visi baru konselor sekolah atau guru BK dalam rangka meningkatkan kualitas layanan pendidikan di sekolah dan madrasah.

\section{METODE PENELITIAN}

Studi ini menggunakan metode penelitian kepustakaan. Disebut penelitian kepustakaan karena data-data atau bahan-bahan yang diperlukan dalam menyelesaikan penelitian tersebut berasal dari perpustakaan baik berupa buku, ensklopedi, kamus, jurnal, dokumen, majalah dan lain sebagainya (Harahap, 2014). Demi kelancaran penelitian ini, peneliti menggunakan tata kerja perpustakaan untuk mengakses dan memperoleh bahan-bahan serta sumber yang diperlukan serta hasil penelitian lain yang relevan dengan penelitian ini. Sumber data dalam penelitian ini adalah buku-buku referensi, jurnal ilmiah, dokumen, majalah, peraturan perundang-undangan dan hasil-hasil penelitian sejenis yang diakses melalui perpustakaan maupun melalui open journal sistem via internet search. Proses pengumpulan data dilakukan dengan cara mencatat dan mengelompokkan data sesuai dengan sub masalah yang dibahas yang kemudian diorganisasikan secara sistematis. Analisis data dilakukan dengan teknik conten analysis atau analisis isi dalam rangka memperoleh teori-teori atau konsep dan hasil penelitian yang mampu menjawab masalah penelitian ini.

\section{HASIL}

\section{Pengertian Guru BK atau Konselor}

Permendikbud No. 111 tahun 2014 pasal 1 ayat 4 (Depdikbud, 2014) menyatakan bahwa Guru Bimbingan dan Konseling adalah pendidik yang berkualifikasi akademik minimal Sarjana Pendidikan (S-1) dalam bidang Bimbingan dan Konseling dan memiliki kompetensi di bidang Bimbingan dan Konseling. Sedangkan (Rini, Justitia, \& Setiawaty, 2016) mendefinisikan bahwa guru BK atau konselor adalah guru yang mempunyai tugas, tanggung jawab, wewenang, dan hak secara penuh dalam kegiatan bimbingan dan konseling terhadap sejumlah peserta didik. Dari kutipan tersebut, secara kompleks dapat diartikan bahwa guru BK adalah tenaga pendidik yang memiliki kualifikasi akademik minimal Sarjana Pendidikan (S-1) dalam bidang Bimbingan dan Konseling dan memiliki kompetensi di bidang Bimbingan dan Konseling serta melaksanakan tugas, 
tanggung jawab, wewenang dan fungsinya secara penuh dalam penyelenggaraan pelayanan konseling di sekolah atau madrasah/ pesantren.

Menurut Permendikbud No. 111 tahun 2014 pasal 1 ayat 3 (Depdikbud, 2014) konselor adalah pendidik profesional yang berkualifikasi akademik minimal Sarjana Pendidikan (S-1) dalam bidang Bimbingan dan Konseling dan telah lulus pendidikan profesi guru Bimbingan dan Konseling/konselor. Sejalan dengan itu menurut Permendiknas No. 27 tahun 2008 tentang SKAKK (Permendiknas, 2008) diartikan bahwa konselor adalah tenaga pendidik profesional yang telah menyelesaikan pendidikan akademik strata satu (S-1) program studi Bimbingan dan Konseling dan program Pendidikan Profesi Konselor dari perguruan tinggi penyelenggara program pengadaan tenaga kependidikan yang terakreditasi. Berdasarkan pengertian tersebut dapat dirumuskan pengertian konselor secara lebih komprehensif yaitu; konselor adalah tenaga pendidik profesional yang memiliki kualifikasi akademik minimal Sarjana Pendidikan strata satu (S-1) program studi Bimbingan dan Konseling dan lulusan program Pendidikan Profesi Konselor yang memiliki kompetensi utuh dalam bidang BK serta melaksanakan tugas, tanggung jawab, wewenang dan fungsinya secara penuh dalam penyelenggaraan pelayanan konseling pada setting sekolah atau madrasah/ pesantren maupun di dunia usaha dan industri dan pada setting masyarakat luas. Pada tabel berikut dapat dilihat perbedaan dan persamaan Guru BK dengan konselor.

Tabel 1. Perbedaan dan Persamaan Guru BK dengan Konselor

Dimensi

Guru BK

\begin{tabular}{lll}
\hline Status & Pendidik* & Pendidik Profesional \\
\hline Pendidikan & Tamatan S.1 BK & Tamatan S.1 BK + PPK \\
\hline Keahlian & $\begin{array}{l}\text { Memiliki Kompetensi dalam bidang } \\
\text { konseling/ BK }\end{array}$ & $\begin{array}{l}\text { Memiliki Kompetensi dalam bidang } \\
\text { konseling/ BK }\end{array}$ \\
\hline Tugas Pokok & $\begin{array}{l}\text { Merencanakan proses pembelajaran } \\
\text { dalam bidang konseling }\end{array}$ & $\begin{array}{l}\text { Merencanakan proses pembelajaran } \\
\text { dalam bidang konseling }\end{array}$ \\
& Melaksanakan proses pembelajaran & $\begin{array}{l}\text { Melaksanakan proses pembelajaran } \\
\text { melalui pelayanan konseling }\end{array}$ \\
& melalui pelayanan konseling & $\begin{array}{l}\text { Melakukan penelitian dalam bidang } \\
\text { konseling }\end{array}$ \\
& Melakukan penelitian dalam bidang \\
& konseling & Siswa, Mahasiswa, dan Masyarakat Luas \\
\hline Sasaran & Terutama Siswa di Sekolah/ & Sekolah dan Madrasah/ Pesantren, dunia \\
& Madrasah/ Pesantren & usaha dan industri, serta Masyarakat \\
& Terutama di Sekolah dan Madrasah/ \\
\hline Setting & Pesantren & \\
& & Luas
\end{tabular}

Guru BK disebut sebagai pendidik profesional jika telah memenuhi persyaratan dan lulus dalam proses sertifikasi pendidik yang dilegitimasi dengan sertifikat pendidik sebagai pengakuan secara formal pendidik profesional.

\section{Posisi/ Keberadaan BK/ Konseling pada Satuan Pendidikan}

BK atau konseling adalah salah satu komponen layanan pendidikan dalam sistem pendidikan nasional, karena pendidikan sebagai suatu sistem diselenggarakan melalui layanan pembelajaran mata pelajaran/ bidang studi, manajemen, layanan bantuan khusus melalui layanan BK/ konseling, dan kegiatan lainnya. Maka dari itu sesuai dengan Permendikbud No. 111 tahun 2014 pasal 5 poin g (Depdikbud, 2014) dapat ditegaskan bahwa BK/ konseling merupakan bagian integral dari proses pendidikan. Beberapa alasan dan argumentasi serta landasan yang menunjukkan keberadaan BK pada satuan pendidikan dapat dilihat berikut ini:

Pertama, ...bimbingan penyuluhan (sekarang BK/ konseling) selalu merupakan momen ilmu mendidik... Ilmu pendidikan dan bimbingan penyuluhan sebagai hal-hal yang esensial untuk umat manusia masa kini dan masa mendatang. Dalam kerangka pemikiran itulah dapat ditandaskan betapa disiplin ilmu mendidik dan bimbingan dan penyuluhan mendapat tempat yang bukan saja wajar, akan tetapi bahkan esensial dalam pendidikan (M. D. Dahlan, 1988). Kedua, konseling adalah pendidikan. Pelayanan konseling adalah pelayanan pendidikan (Prayitno, 2015). Ketiga, Menurut Permendikbud No. 111 tahun 2014 (Depdikbud, 2014) dalam rangka pengembangan 
kompetensi hidup, peserta didik memerlukan sistem layanan pendidikan di satuan pendidikan yang tidak hanya mengandalkan layanan pembelajaran mata pelajaran/ bidang studi dan manajemen, tetapi juga layanan bantuan khusus yang lebih bersifat psiko edukatif melalui layanan BK. Keempat, Menurut Permendikbud No. 111 tahun 2014 (Depdikbud, 2014) bahwa setiap peserta didik satu dengan yang lainnya berbeda kecerdasan, bakat, minat, kepribadian, kondisi pisik dan latar belakang keluarga serta pengalaman belajar, yang menggambarkan adanya perbedaan masalah yang dihadapi peserta didik sehingga memerlukan layanan BK. Kelima, Menurut Permendiknas No. 23 tahun 2006 (Permendiknas, 2006) kompetensi peserta didik yang harus dikembangkan melalui pelayanan BK/ konseling adalah kompetensi kemandirian untuk mewujudkan diri (self actualization) dan pengembangan kapasitasnya (capacity depelopment) yang dapat mendukung pencapaian kompetensi lulusan. Keenam, Menurut Permendikbud No. 111 tahun 2014 (Depdikbud, 2014) bahwa kurikulum 2013 mengharuskan peserta didik menentukan peminatan akademik, vokasi, dan pilihan lintas peminatan serta pendalaman peminatan yang memerlukan layanan bimbingan dan konseling. Ketujuh, pendidikan yang bermutu adalah yang mengintegrasikan tiga bidang kegiatan utamanya secara sinergi, yaitu bidang administrasi dan kepemimpinan, bidang instruksional dan kurikuler, dan bidang pembinaan siswa (bimbingan dan konseling) (Yusuf \& Nurihsan, 2006).

\section{Pergeseran Cara Pandang untuk Mengatasi Kesalahpahaman terhadap BK}

Disadari bahwa selama ini masih terjadi kesalahpahaman terhadap BK. Kesalahpahaman tersebut membuat kehadiran bimbingan dan konseling sebagai salah satu komponen layanan pendidikan belum menunjukkan eksistensinya sebagai layanan pendidikan yang sangat strategis untuk mencapai tujuan pendidikan. Prayitno dalam (Busmayaril \& Heldayani, 2016) di antara kesalahpahaman yang terjadi terhadap bimbingan dan konseling adalah; [1] Bimbingan dan Konseling disamakan atau dipisahkan sama sekali dari pendidikan. [2] Menyamakan pekerjaan Bimbingan dan Konseling dengan pekerjaan dokter dan psikiater. [3] Bimbingan dan Konseling dibatasi pada hanya menangani masalah- masalah yang bersifat insidental. [4] Bimbingan dan Konseling dibatasi hanya untuk peserta didik tertentu saja. [5] Bimbingan dan Konseling melayani "orang sakit" dan/atau "kurang/tidak normal". [6] Bimbingan dan Konseling menangani masalah yang ringan. [7] Petugas Bimbingan dan Konseling di sekolah diperankan sebagai "polisi sekolah". [8] Bimbingan dan Konseling dianggap semata-mata sebagai proses pemberian nasihat. [9] Menganggap pekerjaan bimbingan dan konseling dapat dilakukan oleh siapa saja dll.

Untuk mengatasi kesalahpahaman tersebut maka diperlukan pergeseran pemahaman yang selama ini berkembang kepada pemahaman yang benar terhadap BK sebagaimana tertera pada tabel di bawah ini:

Tabel 2. Formulasi Pergeseran Pemahaman terhadap BK

\section{Pemahaman yang Salah terhadap BK Pemahaman yang Benar terhadap BK}

1. Bimbingan dan Konseling disamakan 1. BK adalah bagian integral dari pendidikan atau dipisahkan sama sekali dari dan tidak dapat dipisahkan dari pendidikan. pendidikan.

2. Menyamakan pekerjaan Bimbingan dan 2. Pekerjaan BK adalah pekerjaan yang Konseling dengan pekerjaan dokter dan bersifat psiko-edukatif dalam bingkai psikiater. budaya yang objek praksis spesifiknya berbeda dengan dokter dan psikiater.

3. Bimbingan dan Konseling dibatasi pada 3. BK adalah pelayanan sepanjang rentang hanya menangani masalah- masalah kehidupan tanpa memandang usia, jenis yang bersifat insidental. kelamin, suku, masalah, dll.

4. Bimbingan dan Konseling dibatasi 4. BK merupkan pelayanan bantuan hanya untuk peserta didik tertentu saja. profesional untuk seluruh peserta didik [guidance and counseling for all].

5. Bimbingan dan Konseling melayani 5. BK melayani individu normal dan bukan "orang sakit" dan/atau "kurang/tidak melayani orang sakit. normal".

6. Bimbingan dan Konseling menangani 6. BK bertujuan memfasilitasi perkembangan masalah yang ringan.

peserta didik secara optimal dan


kemandirian dalam kehidupan.

7. Petugas Bimbingan dan Konseling di sekolah diperankan sebagai "polisi sekolah".

8. Bimbingan dan Konseling dianggap semata-mata sebagai proses pemberian nasihat.

9. Menganggap pekerjaan bimbingan dan konseling dapat dilakukan oleh siapa saja dll.
7. Petugas BK di sekolah diperankan/ berperan sebagai pendidik di sekolah/ madrasah.

8. Layanan BK sebagai bagian dari proses pembelajaran untuk memuat klien berubah.

9. Pekerjaan BK adalah pekerjaan profesional oleh tenaga yang memiliki kualifikasi akademik dan kompetensi/ keahlian dan pengalaman terbimbing dalam bidang konseling yang disebut konselor/ guru BK.

\section{Visi Baru untuk Guru BK/ Konselor Sekolah}

Untuk melakukan reformasi sekolah dan madasah dalam rangka melahirkan pendidikan berkualitas sudah ada kesadaran baru bahwa konselor sekolah harus mempunyai visi masa depan untuk perubahan yang sesuai dengan perkembangan ilmu pengetahuan dan teknologi serta perubahan tatanan kehidupan masyarakat.

Hourse \& Hayes (Gladding, 2012) memaparkan visi baru untuk konselor sekolah abad 21 sebagaimana tertera pada tabel di bawah ini:

Tabel 3. Visi Baru untuk Guru BK/ Konselor Sekolah

\section{Fokus Masa Kini}

\begin{tabular}{llll}
\hline 1. & Penyedia kesehatan mental. & 1. & $\begin{array}{l}\text { Fokus akademis, membangun berdasarkan } \\
\text { kekuatan murid. }\end{array}$ \\
\hline 2. & Permasalahan murid individual. & 2. & Permasalahan seluruh sekolah dan sistem. \\
\hline $\begin{array}{l}\text { 3. } \\
\begin{array}{l}\text { Model klinis berfokus pada kekurangan } \\
\text { murid. }\end{array}\end{array}$ & $\begin{array}{l}\text { 3. } \\
\text { Fokus akademis, membangun berdasarkan } \\
\text { kekuatan murid. }\end{array}$ \\
\hline
\end{tabular}

4. Penyedia layanan 1-1 dan kelompok kecil. 4. Pemimpin, perencana, pengembang program.

5. Fokus utama pada sosial/ personal. $\quad 5$. Fokus pada konseling akademi, pembelajaran dan prestasi, mendukung kesuksesan murid.

6. Personel pendukung tambahan. $\quad$ 6. Anggota integral dari sistem pendidikan.

7. Peran dan tanggung jawab yang 7. Fokus pada misi dan identifikasi peran. didefinisikan secara longgar.
8. Penjaga gerbang.
8. Menggunakan data untuk mempengaruhi perubahan.
9. Penyortir, pemilih dalam bidang proses 9. Pemberi saran untuk keterlibatan dalam penempatan. persiapan yang tepat untuk semua - khususnya murid-murid miskin dan kulit berwarna.

10. Bekerja sendirian atau dengan konselor lain.

\section{Penjaga status quo.}

12. Keterlibatan utama dengan murid.

13. Bergantung pada penggunaan sumber daya system untuk membantu murid dan keluarga.

14. Perencana pasca sekolah menengah atas untuk murid yang berminat.
10. Membuat tim dan berkolaborasi dengan semua pendidik di sekolah dalam memecahkan masalah yang menyangkut seluruh sekolah dan komunitas.

11. Pendorong perubahan, khususnya untuk persamaan pendidikan bagi semua murid.

12. Terlibat dengan murid, orang tua, profesional pendidik, komunitas, badanbadan komunitas.

13. Penyalur layanan bagi orang tua dan murid dari sumberdaya/ badan-badan komunitas serta sumber daya sistem sekolah.

14. Juara dalam menciptakan jalur untuk semua murid guna mencapai cita-citanya yang tinggi. 
Berdasarkan tabel 3 di atas terlihat dengan jelas pergeseran pelayanan konseling pada masa kini dengan visi baru untuk konselor sekolah. Visi baru konselor sekolah ini diyakini dapat memperkuat eksistensi pelayanan konseling profesional dan bermartabat serta menjadi kekuatan dalam meningkatkan kualitas layanan pendidikan di sekolah dan madrasah.

\section{PEMBAHASAN}

Identitas guru BK atau konselor sekolah sebagai tenaga pendidik profesional yang dibekali dengan kualifikasi akademik dan kompetensi di bidang konseling perlu mendapatkan pengakuan yang sehat dan pekerjaan yang bermartabat sesuai dengan hakikat keberadaan profesi konseling dalam upaya meningkatkan kualitas layanan pendidikan. Terkait dengan pembahasan ini, maka dapat ditegaskan bahwa bimbingan dan konseling sebagai bagian integral dari sistem pendidikan dalam upaya meningkatkan kualitas pendidikan harus diampu oleh tenaga pendidik yang memang secara akademik dan kompetensi di bidang konseling yang dipersiapkan dari Perguruan Tinggi yang memiliki program pendidikan tenaga kependidikan yang terakreditasi. Untuk itu, kurikulum pendidikan program studi BK tidak hanya menyajikan sederetan mata kuliah untuk dipelajari dan dikuasai secara kognitif oleh setiap mahasiswa BK, namun sangat diperlukan sederetan pengalaman belajar untuk tercapainya kompetensi yang diharapkan. Hal tersebut diperkuat oleh Rosjidan (Gumilang, 2016b) menyatakan bahwa pengembangan program pendidikan BK tidak cukup memadai jika hanya menstandarisasi daftar mata kuliah yang diperlukan sarjana BK, tetapi juga harus menstandarisasikan pengorganisasian pengalaman belajar mahasiswa yang memungkinkan tercapainya pembentukan sikap pribadi dan kompetensi profesional BK. Ditegaskan lagi oleh (Rakhmawati, 2017) bahwa pengembangan profesionalitas bukanlah sesuatu yang instan melainkan sebuah proses panjang, konselor sekolah harus terus beradaptasi dengan kebutuhan masyarakat agar mereka dapat lebih efektif memenuhi harapan dan kebutuhan siswa.

Menurut Putri, (2016:12) kualitas konselor adalah semua kriteria keunggulan termasuk pribadi, pengetahuan, wawasan, keterampilan, dan nilai-nilai yang dimiliki konselor, yang akan menentukan keberhasilan (efektivitas) proses bimbingan dan konseling. Salah satu kualitas adalah kualitas pribadi konselor, yang menyangkut segala aspek kepribadian yang amat penting dan menentukan efektivitas konseling. Kualitas pribadi konselor sekolah yang menyangkut berbagai aspek yang melekat pada dirinya menjadi significan person sebagai cermin bagi konseli dan lingkungannya. Di samping itu, konselor sekolah harus memiliki wawasan yang luas, berpikiran cerdas, dan berbuat tangkas serta memiliki visi yang jelas untuk meningkatkan kualitas layanan pendidikan melalui pelayanan konseling. Maka dari itu, posisi layanan bimbingan dan konseling tidak dalam kapasitas hanya untuk membantu siswa yang bermasalah, akan tetapi untuk memfasilitasi perkembangan siswa secara optimal. Sejalan dengan itu, (Z. Dahlan, 2017) menguraikan bahwa konselor profesional memberikan layanan berupa pendampingan (advokasi) pengkoordinasian, mengkolaborasi dan memberikan layanan konsultasi yang dapat menciptakan peluang yang setara dalam meraih kesempatan dan kesuksesan bagi konseli berdasarkan prinsip-prinsip profesionalitas yaitu; (1) setiap individu memiliki hak untuk dihargai dan mendapatkan kesempatan untuk memperoleh layanan bimbingan dan konseling. Konselor memberikan pendampingan bagi individu dari berbagai latar belakang kehidupan yang beragam dalam budaya, etnis, agama dan keyakinan, usia, status sosial, dan ekonomi, individu dengan kebutuhan khusus, individu yang mengalami kendala bahasa, dan identitas gender. (2) setiap individu berhak memperoleh informasi yang mendukung kebutuhannya untuk mengembangkan dirinya. (3) setiap individu mempunyai hak untuk memahami arti penting dari pilihan hidup dan bagaimana pilihan tersebut akan mempengaruhi masa depannya, dan (4) setiap individu memiliki hak untuk dijaga kerahasiaan pribadinya sesuai dengan aturan hukum, kebijakan, dan standar etika layanan.

Lebih lanjut, konselor sekolah harus cerdas dan kreatif dalam memanfaatkan peluang di samping memperkuat kapasitas pribadinya dengan kemampuan manajemen sehingga mampu memanfaatkan sumber daya yang ada di sekitarnya dalam melaksanakan konseling profesional. Untuk itu, secara rinci dan operasional Sink, C. A. (Rakhmawati, 2017) menjelaskan bahwa perkembangan abad 21 yang serba mudah, mendorong konselor sekolah untuk tetap fokus pada: (1) mengembangkan dan memperbarui keterampilan yang dibutuhkan untuk melayani semua siswa. (2) menjelajahi inovasi dalam pendidikan dan konseling baik secara teori dan praktek. (3) advokasi untuk diri mereka sendiri dan program mereka. (4) melaksanakan program yang komprehensif yang dirancang dengan baik. (5) berkolaborasi dengan pihak lain, personil sekolah, dan dengan lembaga-lembaga dan program masyarakat. (6) memfasilitasi siswa baik kebutuhan maupun program prestasi. (7) membuat komunitas yang nyaman di sekolah, dan (8) menunjukkan profesionalisme tingkat tinggi. Sebagai tenaga profesi konseling, peran primer konselor adalah melaksanakan 
konseling, baik konseling individual, konseling kelompok, konseling keluarga, konseling karir, konseling pendidikan, konsultasi dengan guru, konsultasi dengan orang tua, dan evaluasi layanan bimbingan dan konseling, serta menfasilitasi rujukan ke lembaga atau ahli di luar lingkungan sekolah (Wibowo, 2017). Di samping itu, untuk meningkatkan kualitas layanan pendidikan di sekolah dan madrasah, khususnya melalui pelayanan konseling, maka sangat diperlukan penelitian dan evaluasi terhadap pelaksanaan program bimbingan dan konseling secara berkelanjutan. Hal ini ditegaskan oleh (Ardimen, 2016) bahwa in addition to the approaches and techniques of counseling, one approach that can be used by guidance and counseling teachers/counselors to improve the quality of the process and results of counseling services is research. Karena dengan meneliti dapat mengevaluasi proses dan hasil pembelajaran secara akuntabel dengan instrumen tertentu untuk peningkatan proses dan hasil pembelajaran berikutnya (Ardimen, 2017). Sejalan dengan itu, studi (Gumilang, 2016a) menyatakan bahwa evaluasi pelaksanaan program BK merupakan suatu usaha untuk menilai efisiensi dan efektivitas pelayanan bimbingan dan konseling demi peningkatan mutu program bimbingan dan konseling.

\section{SIMPULAN DAN SARAN}

Beberapa kesimpulan dapat disajikan berdasarkan uraian terdahulu yaitu:

1. Kinerja konselor sekolah tidak lagi diposisikan dalam upaya bantuan untuk mengatasi masalah siswa di sekolah dan madrasah, namun konselor melaksanakan konseling untuk membantu individuindividu normal yang sedang menjalani proses perkembangan sesuai dengan tahap-tahap perkembangannya agar mencapai perkembangan optimal, kemandirian dan kebahagiaan dalam menjalani kehidupan.

2. Konselor adalah tenaga pendidik profesional yang memiliki kualifikasi akademik minimal Sarjana Pendidikan strata satu (S-1) program studi Bimbingan dan Konseling dan lulusan program Pendidikan Profesi Konselor yang memiliki kompetensi utuh dalam bidang BK serta melaksanakan tugas, tanggung jawab, wewenang dan fungsinya secara penuh dalam penyelenggaraan pelayanan konseling pada setting sekolah atau madrasah/ pesantren maupun di dunia usaha dan industri dan pada setting masyarakat luas.

3. Guru BK adalah tenaga pendidik yang memiliki kualifikasi akademik minimal Sarjana Pendidikan (S-1) dalam bidang Bimbingan dan Konseling dan memiliki kompetensi di bidang Bimbingan dan Konseling serta melaksanakan tugas, tanggung jawab, wewenang dan fungsinya secara penuh dalam penyelenggaraan pelayanan konseling di sekolah atau madrasah/ pesantren.

4. Visi baru konselor sekolah bertumpu pada; (1) fokus akademis/ prestasi murid, (2) membangun berdasarkan kekuatan murid, (3) konselor sebagai pemimpin, perencana, dan pengembang program, (4) berfokus pada konseling akademi, pembelajaran dan prestasi, serta mendukung kesuksesan murid, (5) konseling menjadi bagian integral dari sistem pendidikan, (6) layanan konseling berfokus pada misi dan identifikasi peran, (7) menggunakan data untuk mempengaruhi perubahan, (8) pemberi saran untuk keterlibatan dalam persiapan yang tepat untuk semua, (9) membuat tim dan berkolaborasi dengan semua pendidik di sekolah dalam memecahkan masalah yang menyangkut seluruh sekolah dan komunitas, (10) konselor sebagai pendorong perubahan, khususnya untuk persamaan pendidikan bagi semua murid, (11) terlibat dengan murid, orang tua, profesional pendidik, komunitas, badan-badan komunitas, (12) penyalur layanan bagi orang tua dan murid dari sumberdaya/ badan-badan komunitas serta (13) sumber daya sistem sekolah dan (14) juara dalam menciptakan jalur untuk semua murid guna mencapai cita-citanya yang tinggi.

Beberapa saran untuk menjadi pertimbangan dalam meningkatkan kualitas layanan pendidikan melaui pelayanan konseling yaitu:

1. Guru BK diharapkan selalu meningkatkan pengetahuan, keterampilan, kepribadian dan kreativitasnya melalui kegiatan seminar, workshop, pendidikan dan pelatihan serta rajin mengupgrade perkembangan ilmu bimbingan dan konseling.

2. Kepala sekolah dan kepala madrasah diharapkan memfasilitasi guru BK/ konselor untuk mengikuti kegiatan-kegiatan ilmiah dalam forum MGBK, diklat dan lainnya.

3. Di dalam forum Musyawarah Kerja Kepala Sekolah (MKKS) atau forum Musyawarah Kerja Kepala Madrasah (MK2M) diharapkan ada pembahasan atau diskusi dan pelatihan tentang manajemen BK di sekolah dan madrasah.

4. Kepala Dinas Pendidikan dan Kementerian Agama diharapkan dapat membuat kebijakan untuk mengadaan dan peningkatan kompetensi guru BK/ konselor. 
5. Diharapkan kepada pengurus ABKIN Kabupaten dan MGBK untuk intensif melakukan penelitian dan pengembangan profesi dan berbagi pengalaman untuk meningkatkan mutu layanan BK dan mutu pendidikan di tempat tugas masing-masing.

6. Peneliti selanjutnya, dapat melakukan penelitian sejenis dengan menggunakan variabel yang berbeda misalnya kepribadian konselor di sekolah dan madrasah, hubungan empati konselor dengan minat siswa mengikuti layanan konseling di sekolah dan madrasah, dan lainnya.

\section{DAFTAR RUJUKAN}

Ardimen, A. (2016). Counseling Services Based Research to Improve the Quality of Learning Through Counseling. GUIDENA: Jurnal Ilmu Pendidikan, Psikologi, Bimbingan Dan Konseling, 6(2), 164-171.

Ardimen, A. (2017). Rekonstruksi Kinerja Pendidik Melalui Pembelajaran dan Pelayanan Konseling Berbasis Riset. In Proceeding Batusangkar International Conference I (Vol. 1, pp. 165-180).

Busmayaril, B., \& Heldayani, H. (2016). Persepsi Peserta Didik Terhadap Pelaksanaan Bimbingan dan Konseling di Sekolah Menengah Atas Negeri I Karya Penggawa Kabupaten Pesisir Barat Tahun Pelajaran 2015/2016. KONSELI: Jurnal Bimbingan Dan Konseling (E-Journal), 3(1), 11-18.

Dahlan, M. D. (1988). Posisi Bimbingan dan Penyuluhan Pendidikan dalam Kerangka Ilmu Pendidikan. Pidato Pengukuhan Jabatan Guru Besar dalam Ilmu Pendidikan pada FIP IKIP Bandung, tanggal 9 April 1988.

Dahlan, Z. (2017). Peningkatan Kualitas Kompetensi Guru BK Sebagai Konselor di Sekolah dalam Menghadapi Tantangan Global. Al-Irsyad, 8(1), 8-17.

Depdikbud. (2014). Peraturan Menteri Pendidikan dan Kebudayaan Republik Indonesia Nomor 111 tahun 2014 tentang Bimbingan dan Konseling pada Pendidikan Dasar dan Pendidikan Menengah. Jakarta: Depdikbud.

Gladding, S. T. (2012). Konseling: Profesi yang Menyeluruh. (alih bahasa: P.M Winarno), Edisi Keenam. Jakarta: Indeks.

Gumilang, G. S. (2016a). Evaluasi Keterampilan Komunikasi Interpersonal Antara Konselor Dengan Siswa, Staf Sekolah, dan Orangtua SMKN di Kota Malang. JKI (Jurnal Konseling Indonesia), 1(2), 76-82.

Gumilang, G. S. (2016b). Penajaman Karakteristik Pribadi Konselor pada Mahasiswa Jurusan Bimbingan dan Konseling. In Prosiding Seminar Nasional dan Call for Paper ke-2 "Pengintegrasian Nilai Karakter dalam Pembelajaran Kreatif di Era Masyarakat Ekonomi ASEAN."

Harahap, N. (2014). Penelitian Kepustakaan. Iqra': Jurnal Perpustakaan Dan Informasi, 8(1), 68-74.

Mustadi, A. (2018). Reformasi Sekolah melalui Learning Community based Lesson Study (LCLS) di Sekolah Dasar. Inopendas, 1(1), 9-15.

Permendiknas. (2006). Peraturan Menteri Pendidikan Nasional Nomor 23 Tahun 2006 Tentang Standar Kompetensi Lulusan. Jakarta: Departemen Pendidikan Nasional.

Permendiknas. (2008). Peraturan Menteri Pendidikan Nasional Nomor 27 Tahun 2008 tentang Standar Kualifikasi Akademik dan Kompetensi Konselor. Jakarta: Departemen Pendidikan Nasional.

Prayitno. (2015). Konseling Integritas (Pola Konseling Indonesia). Yogyakarta: Paramitra Publishing.

Rakhmawati, D. (2017). Konselor Sekolah Abad 21: Tantangan dan Peluang. Jurnal Konseling GUSJIGANG, 3(1), 58-63.

Rini, D. S., Justitia, D., \& Setiawaty, R. D. (2016). Kompetensi Kepribadian Guru BK (Survei pada Guru Bimbingan dan Konseling Sekolah Menengah Pertama dan Sederajat se-Kecamatan Citeureup). Insight: Jurnal Bimbingan Konseling, 5(1), 153-159.

Wibowo, M. E. (2017). Profesi Konselor dalam Kurikulum 2013 dan Permasalahannya. Jurnal Bimbingan Dan Konseling Terapan, 1(2), 63-85.

Yusuf, S., \& Nurihsan, A. J. (2006). Landasan Bimbingan \& Konseling. Bandung: Remaja Rosdakarya. 